\title{
Front Matter: Volume 9656
}

, "Front Matter: Volume 9656," Proc. SPIE 9656, International Symposium on Photonics and Optoelectronics 2015, 965601 (26 August 2015); doi:

$10.1117 / 12.2205193$ SPIE. Event: International Symposium on Photonics and Optics, 2015, Shanghai, 


\section{PROCEEDINGS OF SPIE}

\section{International Symposium on Photonics and Optoelectronics 2015}

Zhiping Zhou

Editor

22-24 August 2015

Shanghai, China

Organized by

Wuhan University (China)

Sponsored by

Wuhan University (China)

Beijing University of Posts and Telecommunications (China)

State Key Laboratory of Information Photonics and Optical Communications (China)

SCONTEL (Russian Federation)

Published by

SPIE

Volume 9656 
The papers included in this volume were part of the technical conference cited on the cover and title page. Papers were selected and subject to review by the editors and conference program committee. Some conference presentations may not be available for publication. The papers published in these proceedings reflect the work and thoughts of the authors and are published herein as submitted. The publisher is not responsible for the validity of the information or for any outcomes resulting from reliance thereon.

Please use the following format to cite material from this book:

Author(s), "Title of Paper," in International Symposium on Photonics and Optoelectronics 2015, edited by Zhiping Zhou, Proceedings of SPIE Vol. 9656 (SPIE, Bellingham, WA, 2015) Article CID Number.

ISSN: 0277-786X

ISBN: 9781628418699

Published by

SPIE

P.O. Box 10, Bellingham, Washington 98227-0010 USA

Telephone +1 3606763290 (Pacific Time) · Fax +1 3606471445

SPIE.org

Copyright (@ 2015, Society of Photo-Optical Instrumentation Engineers.

Copying of material in this book for internal or personal use, or for the internal or personal use of specific clients, beyond the fair use provisions granted by the U.S. Copyright Law is authorized by SPIE subject to payment of copying fees. The Transactional Reporting Service base fee for this volume is $\$ 18.00$ per article (or portion thereof), which should be paid directly to the Copyright Clearance Center (CCC), 222 Rosewood Drive, Danvers, MA 01923. Payment may also be made electronically through CCC Online at copyright.com. Other copying for republication, resale, advertising or promotion, or any form of systematic or multiple reproduction of any material in this book is prohibited except with permission in writing from the publisher. The CCC fee code is 0277-786X/15/\$18.00.

Printed in the United States of America.

Publication of record for individual papers is online in the SPIE Digital Library.

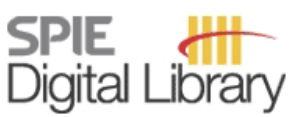

SPIEDigitalLibrary.org

Paper Numbering: Proceedings of SPIE follow an e-First publication model, with papers published first online and then in print. Papers are published as they are submitted and meet publication criteria. A unique citation identifier (CID) number is assigned to each article at the time of the first publication. Utilization of CIDs allows articles to be fully citable as soon as they are published online, and connects the same identifier to all online, print, and electronic versions of the publication. SPIE uses a six-digit CID article numbering system in which:

- The first four digits correspond to the SPIE volume number.

- The last two digits indicate publication order within the volume using a Base 36 numbering

system employing both numerals and letters. These two-number sets start with 00, 01, 02, 03, 04, $05,06,07,08,09,0 A, 0 B \ldots$. 0Z, followed by 10-1Z, 20-2Z, etc.

The CID Number appears on each page of the manuscript. The complete citation is used on the first page, and an abbreviated version on subsequent pages. 


\title{
Contents
}

\author{
vii Authors \\ ix Conference Committee \\ xi Introduction
}

\section{LASER TECHNOLOGY AND APPLICATIONS; OPTICAL COMMUNICATIONS}

965602 Diffraction imaging characteristics of slit for ultra-short laser pulse [9656-104]

965603 Second harmonic measurement of multi-beam laser heterodyne with ultra-precision for the small angle [9656-108]

965604 Waveguide laser in Nd:YAG planar waveguide produced by $1.4 \mathrm{GeV} \mathrm{Kr}$ ion irradiation [9656-111]

965605 852nm up-conversion lasing characteristics based on $\mathrm{Er}^{3+}$-doped silica fiber [9656-114]

965606 Research on ultrasonic vibration aided femtosecond laser machining process of transparent materials [9656-116]

965607 Nonlinear Cerenkov radiation in $\mathrm{a} \mathrm{LiTaO}_{3}$ waveguide with annular poling domain [9656-120]

965608 Using an active temporal compensating system to achieve the super-Gaussian pulses in high-power lasers [9656-122]

965609 A low cost design to eliminate polarization induced phase shift for dual Mach-Zehnder fiber interferometer [9656-124]

9656 OA Sub-picosecond double-clad photonic crystal fiber oscillator and amplifier system [9656-125]

9656 OB High-energy, high-peak power single-frequency 10 ns pulsed fiber amplifier [9656-132]

9656 OC Simulation study on transverse mode of laser resonator [9656-133]

9656 OD The simulation of scattering and absorption coefficient in the course of laser transmission [9656-134]

9656 OE Investigation of Raman spectra of polyethylene terephthalate [9656-148] 
OPTOELECTRONIC DEVICES AND INTEGRATION, IMAGE PROCESSING; MEDICAL AND BIOLOGICAL APPLICATIONS

9656 OF An image mosaic method based on corner [9656-4]

9656 OG Fast image mosaic algorithm based on the improved Harris-SIFT algorithm [9656-7]

$9656 \mathrm{OH} \quad$ Preparation of boron doped silicon films for its application in solar cells [9656-10]

9656 Ol The compensation effects of temperature variation in long-term videometric measurement [9656-12]

$96560 \mathrm{~J} \quad$ Multi-curvities femtosecond laser aided microstructures for magnetic field sensing [9656-16]

9656 OK Dispersion and compensation of optical coherence tomography using double-path rapid scanning optical delay line [9656-17]

$9656 \mathrm{OL}$ Research on duality of optical effect based on inverse operation of tensor [9656-18]

$96560 \mathrm{M} \quad$ Measurement method of sky background infrared radiation characteristic based on infrared image inversion [9656-21]

9656 ON Study on the elemental mercury absorption cross section based on differential optical absorption spectroscopy [9656-24]

965600 Ambient temperature normalization for infrared face recognition based on the secondorder polynomial model [9656-28]

9656 OP Biasing dependent circuit modeling and optimization of resonant cavity enhanced PIN photodetectors (RCE-PIN-PDs) [9656-30]

$96560 Q \quad$ Electroluminescence spectrum in amorphous-Si/ silicon oxynitride multilayer structures [9656-32]

9656 OR Strong blue light emission from Eu-doped SiOC prepared by magnetron sputtering [9656-33]

9656 OS Infrared gas detection based on an adaptive Savitzky-Golay algorithm [9656-34]

9656 OT High bandwidth based on a tapped-delay-line equalization in visible light communications [9656-36]

9656 OU Effect of oxygen partial pressure and anneal temperature on $\mathrm{BaTiO}_{3}$ thin film crystal structure [9656-37]

9656 OV An automatic blood cell segmentation method based on hyperspectral imaging technology [9656-38]

9656 OW TCAD analysis of graphene silicon Schottky junction solar cell [9656-40] 
$96560 \mathrm{X}$ Study on fiber Bragg grating strain sensing array detecting multi-crack damage of cantilever beam [9656-41]

9656 OY The study of stereo vision technique for the autonomous vehicle [9656-43] 
Proc. of SPIE Vol. $9656965601-6$

Downloaded From: https://www.spiedigitallibrary.org/conference-proceedings-of-spie on 26 Apr 2023 Terms of Use: https://www.spiedigitallibrary.org/terms-of-use 


\title{
Authors
}

Numbers in the index correspond to the last two digits of the six-digit citation identifier (CID) article numbering system used in Proceedings of SPIE. The first four digits reflect the volume number. Base 36 numbering is employed for the last two digits and indicates the order of articles within the volume. Numbers start with 00, 01, 02, 03, 04, 05, 06, 07, 08, 09, OA, OB...0Z, followed by 10-1Z, 20-2Z, etc.

\author{
Bai, Xiaonan, OT \\ Chao, Zhichao, ol \\ Chen, C. D., 07 \\ Chen, Feng, 04 \\ Cheng, Xiangzheng, OM \\ Cheng, Yazhou, 04 \\ Chi, Junjie, OA, OB \\ Dai, Yutang, 06, 0J \\ Deng, Hao, OS \\ Ding, Q., 03 \\ El-Batawy, Yasser M., OP \\ Feng, Jinfu, OW \\ Fu, Sihua, Ol \\ Fu, Xiuhua, OU \\ Guo, Fangmin, OV \\ Guo, Xujing, OT \\ Guo, Yanqing, $\mathrm{OH}, \mathrm{OQ}, \mathrm{OR}$ \\ Guo, Zhizhong, OL \\ $\mathrm{He}$, Weiming, 08 \\ $\mathrm{Hu}$, Haowei, $\mathrm{OB}$ \\ $\mathrm{Hu}$, Huxiang, $\mathrm{OM}$ \\ $\mathrm{Hu}, \mathrm{X} . \mathrm{P} ., \mathrm{O} 7$ \\ Huang, Rui, $\mathrm{OH}, \mathrm{OQ}, \mathrm{OR}$ \\ Huang, Xiaoyuan, $\mathrm{OK}$ \\ Jiang, Guangwen, $\mathrm{Ol}$ \\ Jiang, Zetao, OF, OG \\ Karanja, Joseph Muna, 06, 0J \\ Kuang, Yawei, OW \\ Li, Ai-jun, OD \\ $L i$, Jingsong, OS \\ Li, Pei, OY \\ Li, Pengfei, OS \\ Li, Pingxue, OA, OB \\ Li, Qingli, OV \\ Li, Rui, 09 \\ Li, Sensen, 08 \\ Li, Tao, 06 \\ Li, Y. Chao, 03 \\ Liang, Boxing, $O A, O B$ \\ Liang, Sheng, 09 \\ Lin, Zhenxu, OR \\ Ling, Dongxiong, OK \\ Liu, Bin, 06, 0J \\ Liv, C. Yu, 03 \\ Liu, Dong-mei, OU \\ Liu, Hongliang, 04 \\ Liu, Hongying, OV \\ Liu, Jianan, OL \\ Liv, Min, OG
}

\author{
Liv, Qianzhe, 09 \\ Liu, Rui, 08 \\ Liu, Yang, 05 \\ LiU, Yu, OS \\ Liu, Yushen, OW \\ Liv, Zhaohong, 08 \\ Lu, Chang-yong, 05 \\ Lu, Long-zhao, 02 \\ Luo, Pei, OX \\ Lv, Zhiwei, 08 \\ Ma, Chunmei, OB \\ $\mathrm{Ma}$, Yulong, OW \\ Medhat, Marina, OP \\ Nie, Heting, OF \\ Pan, Yong-gang, OU \\ Qiao, Yang, OD \\ Shao, Ming, OM \\ Shen, Xiao-fang, OD \\ Song, Chao, OH, OQ, OR \\ Song, Jie, $\mathrm{OH}, \mathrm{OQ}, \mathrm{OR}$ \\ Song, Lixin, $\mathrm{OE}$ \\ Sun, De-gui, OU \\ Sun, Hong-hui, OD \\ Sun, J. Feng, 03 \\ Tian, Jianwei, OX \\ Tong, Na, OE \\ Wang, C. Hui, 03 \\ Wang, Chao, OT \\ Wang, Jiang-feng, OY \\ Wang, Lian-fen, OD \\ Wang, Qian, OV \\ Wang, $X i, O Y$ \\ Wang, Xiang, $\mathrm{OH}, \mathrm{OQ}, \mathrm{OR}$ \\ Wang, Y. Qiao, 03 \\ Wang, Yukun, OL \\ Wang, Yulei, 08 \\ Wang, Zhengzi, 00 \\ Wu, Kun-xi, 02 \\ Xiao, Wen, 09 \\ $X U$, Jing, OW \\ $X U$, Yongzhao, OK \\ Yang, Chun, OB \\ Yang, Fei, OU \\ Yang, J. Ru, 03 \\ Yang, Xifeng, OW \\ Yang, Z., OC \\ Yao, Penghui, ON \\ Yao, Yifei, OB \\ Ye, Hai, OK
}


Yin, Guanglin, 06

Yu, Benli, OS

Yu, Qifeng, Ol

Yu, Xiang-yang, 02

Yuan, Hang, 08

Zhai, Xiangwen, OT

Zhang, Guangju, OB

Zhang, Guoging, $\mathrm{OE}$

Zhang, Jing, OU

Zhang, Liwen, OM

Zhang, Mengmeng, $\mathrm{OA}, \mathrm{OB}$

Zhang, Minglun, OT

Zhang, Xi, 05

Zhang, Yi, OR

Zhao, Yinan, OL

Zhao, Ziqiang, OB

Zheng, Haiming, $\mathrm{ON}$

Zhou, L. F., OC

Zhou, Mei, OV

Zhou, Xian, OJ

Zhu, Changjun, $\mathrm{OE}$

Zhu, Hetian, OT

Zhu, Xuehua, 08

Zou, H., OC 


\title{
Conference Committee
}

\author{
Conference Chair
}

Zhiping Zhou, Peking University (China)

Program Committee Chair

Yongzhen Huang, Institute of Semiconductors, CAS (China)

Program Committee Co-chair

Khaled Habib, Materials Science and Photo-Electronics Laboratory, IRE Program, EBR Center (Kuwait)

Program Committee

Mohamed Swillam, American University in Cairo (Egypt)

Sriramulu Mohan, Vel Tech University (India)

Pablo Sanchis Kilders, Universidad Politécnica de Valencia (Spain)

Zabih Ghassemlooy, Northumbria University (United Kingdom)

Qingguo Du, Institute of High Performance Computing (Singapore)

Wenjie Wan, Shanghai Jiao Tong University (China)

Jian Wang, Huazhong University of Science \& Technology (China)

Zhipei Sun, Aalto University (Finland)

John Marsh, University of Glasgow (United Kingdom)

Shug-June Hwang, National United University (Taiwan, China)

Jitendra Nath Roy, National Institute of Technology, Agartala (India)

Sajan. D. George, Manipal University (India)

Ching-Fuh Lin, National Taiwan University (Taiwan, China)

Xiaomin Ren, Beijing University of Posts and Telecommunications

(China)

C. K. Jayasankar, Sri Venkateswara University (India)

Ping Xue, Tsinghua University (China)

Noel Healy, University of Southampton (United Kingdom)

Xingcan Dai, Tsinghua University (China)

Guoquan Zhang, Nankai University (China)

Alexey Seteikin, Amur State University (Russian Federation)

Jacob Dunningham, University of Sussex (United Kingdom)

Chong Leong Gan, Spansion Penang (Malaysia)

Sergei Popov, Royal Institute of Technology (Sweden)

Frank Bertram, University of Magdeburg (Germany)

Mohammed Shabat, Islamic University of Gaza (Palestine) 
Kaikai Xu, University of Electronic Science and Technology of China (China)

Sergey V. Sergeyev, Aston University (United Kingdom)

Young Pak Lee, Hanyang University (Korea, Republic of)

Abdelkader Makhoute, Université Moulay Ismail (Morocco)

Local Organizing Committee

Fang Liu, Wuhan University (China)

Liang Li, Wuhan University (China)

Ruoshan Kong, Wuhan University (China)

Xiaoyan Sheng, Wuhan University (China)

Yuanyuan Cheng, Wuhan University (China)

Yujing Zhang, Wuhan University (China) 


\section{Introduction}

It is my great pleasure to present this proceedings volume of papers from the International Symposium on Photonics and Optoelectronics (SOPO), held 22-24 August 2015 in Shanghai, China. I would like to take this opportunity to thank all the authors and participants for their support to our conference.

With the development of technology, a great variety of research results are emerging. Following the rapid development trend, SOPO 2015 serves as a forum for the academic professionals and researchers to exchange the most updated information and achievements in those exciting research areas.

On behalf of the organizing committee, I would like to express our gratitude to our sponsors: Wuhan University, Beijing University of Posts and Telecommunications, State Key Laboratory of Information Photonics and Optical Communications, and SCONTEL. At the same time, we appreciate the contributions from our paper reviewers and the committee members. Your efforts make the conference a success.

These proceedings provide a concise but timely medium for the dissemination of recent research results. I hope that you find this proceedings volume interesting, exciting, and informative.

Thanks again for your attention and support to our conference.

Zhiping Zhou 
Proc. of SPIE Vol. $9656965601-12$

Downloaded From: https://www.spiedigitallibrary.org/conference-proceedings-of-spie on 26 Apr 2023 Terms of Use: https://www.spiedigitallibrary.org/terms-of-use 